African Crop Science Journal by African Crop Science Society is licensed under a Creative Commons Attribution 3.0 Uganda License. Based on a work at www.ajol.info/ and www.bioline.org.br/cs DOI: https://dx.doi.org/10.4314/acsj.v28i3.7

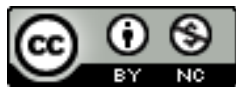

\title{
EFFICIENCY AND POSSIBILITIES FOR ARABICA COFFEE-BANANA MANAGEMENT SYSTEMS SWITCHING IN THE MT. ELGON LANDSCAPE OF UGANDA
}

\author{
C. SEBATTA, J. MUGISHA, F. BAGAMBA, E.A. NUPPENAU' ${ }^{1}$, S.E. DOMPTAIL ${ }^{1}$, \\ A. IJALA ${ }^{2}$ and J. KARUNGI ${ }^{2}$ \\ Department of Agribusiness and Natural Resource Economics, Makerere University, \\ P. O. Box 7062, Kampala, Uganda \\ ${ }^{1}$ Department of Agricultural Policy and Market Research, University of Giessen, Germany \\ ${ }^{2}$ Department of Agricultural Production, Makerere University, P. O. Box 7062, Kampala, Uganda \\ Corresponding author: sebattac@gmail.com
}

(Received 14 December 2019; accepted 28 August 2020)

\begin{abstract}
Sustainably intensifying rural agricultural systems is now a development goal that has gained momentum in the recent decades due to a rapidly growing population and feeds directly into the Sustainable Development Goals of ending poverty and hunger. By 2050, the world will be inhabited by 10 billion people, $68 \%$ of whom will be city dwellers which will pose serious food and livelihoods security threats to millions of people, especially in Sub-Saharan Africa. The objective of this study was to analyse technical efficiency of four production systems in Arabica coffee-banana farming system of the Mt. Elgon in Uganda and assesses possibilities for switching from one system to another. The study was motivated by the notion that smallholder farmers do not easily adopt new systems because of opportunity costs related to input substitution, input and/or efficiency reduction and systems redesigning. We estimated a production function to measure technical efficiency and ordered the intensification pathways to create a Technical Efficiency (TE) gradient. An ordered logit model was then estimated to determine the factors influencing farmers to switch among systems, by adopting one or more following a TE gradient. Results showed that farmers produced 50\% of the maximum possible Arabica coffee output, indicating huge gaps between actual and potential yields. Use of fertiliser for the lowest efficiency. Low-input-low-output pathway and improved coffee genotypes, manure and labour intensification for the higher technical efficiency clusters such as conventional and mild agroecological would also significantly increase the chances of switching from low to highly efficient and sustainable Arabica coffee production systems in the Mt. Elgon watershed of Uganda.
\end{abstract}

Key Words: Mountain watershed, Ordered logit, production function 
L'intensification durable des systèmes agricoles ruraux est un objectif de développement durable qui a été pris en compte pour mettre fin à la pauvreté et la faim dans une population en croissance rapide. Le monde sera habité par 10 milliards de personnes, dont $68 \%$ seront des citadins en 2050 , ce qui posera de graves menaces à la sécurité alimentaire et des moyens de subsistance de millions de personnes, en particulier en Afrique Sub-Saharienne. L'objectif de cette étude était d'analyser l'efficacité de technique de quatre systèmes de production dans le système de culture café-banane Arabica du mont Elgon en Ouganda et évalue les possibilités de passer d'un système à un autre. L'étude était motivée par l'idée que les petits exploitants agricoles n'adoptent pas facilement de nouveaux systèmes en raison des coûts d'opportunité liés à la substitution des intrants, la réduction des intrants et / ou de l'efficacité et la refonte des systèmes. Nous avons estimé une fonction de production pour mesurer l'efficacité de technique et nous avons ordonné les voies d'intensification pour créer un gradient l'efficacité de technique (TE). Un modèle logit ordonné a ensuite été estimé pour déterminer les facteurs qui poussent les agriculteurs à basculer entre les systèmes, en adoptant un ou plusieurs suivant un gradient TE. Les résultats ont montré que les agriculteurs produisaient $50 \%$ de la production maximale possible de café Arabica, indiquant d'énormes écarts entre les rendements réels et potentiels. Utilisation d'engrais pour une efficacité minimale. Une filière à faibles intrants et à faible rendement et des génotypes de café améliorés, du fumier et une intensification de la main-d'œuvre pour les grappes à plus haute efficacité de technique telles que l'agroécologie conventionnelle et douce augmenteraient également considérablement les chances de passer de systèmes de production de café Arabica faibles à très efficaces et durables dans le bassin versant du Mont Elgon en Ouganda.

Mots Clés: Bassin versant de montagne, logit ordonné, fonction de production

\section{INTRODUCTION}

The continued global surge in human populations has led to a steady increase in competition for limited land resources over time. Many countries, especially in SubSaharan Africa (SSA) are experiencing a progressive expansion of their agricultural lands and rural settlements into the natural landscape, which has grave environmental and ecosystem consequences (Ellis et al., 2010; Gracheva et al., 2012). In addition, research shows that agricultural growth, especially in SSA has been declining since 2007, from $3.5 \%$ p.a, and is projected to fall to $2.1 \%$ p.a by 2030-2050 (Alexandratos and Bruinsma, 2012).

As land pressures continue to rise, the land management debate seems to have shifted from extensification to intensification to save the situation. In SSA, the traditional intensification pathway has been tightly linked to labour intensification, by increasing yields via greater labour inputs (Boserup, 2014; Ruthenberg, 1971), though it has often resulted into expansion of agriculture into the natural ecosystems (Burton and White, 1984).

In Uganda, the ongoing mass deforestation and cultivation on the slopes of Mt. Elgon due to a rapidly growing population, is causing land use change and increased risk of landslides and soil loss (Jiang et al., 2014; Mugagga et al., 2012; Kitutu et al., 2009; Claessens et al., 2007; Knapen et al.,2006). These practices have exacerbated land degradation, pest and disease escalation, and soil and land cover loss, leading to reduced productivity and posing serious threats on food security (Wasige et al., 2007; Mugagga et al., 2012). It is, therefore, not surprising that as the global coffee production increased by about $2 \%$ between 2012 and 2017, and the world production tending to triple to 300 million coffee bags by 2050 (World Coffee Research Report, 2017), Uganda's coffee production is on the 
downward spiral (Hakiza et al., 2010; Verter et al., 2015).

Farmers who are faced with reducing farm productivity that threatens their livelihoods, food and income security have to make a choice to either improve on their current production systems or switch to more productive and efficient ones. Much as the farmer's choice of land management systems is a subject that has been researched widely, switching from one system to another, and what may drive it has not received much attention. This is partly due to the assumption that farmers do not easily change once they take on a production system (Drost et al., 1996) and that a land use switch does not follow a fixed pattern, nor is it deterministic (Lambin and Meyfroidt, 2010).

Land use and management switching involves three opportunity cost processes that make it hard for many resource-poor farmers, that is, input substitution, input and or efficiency reduction and systems redesign (Lamine, 2011). Land management systems switching, however, has been documented in the "conventional to organic" farming change as mainly driven by farmers' monetary motives such as premium prices and cost saving (Padel, 2001), non-financial inducements (Lohr and Salomonsson, 2000) or for safety and environmental reasons (Fairweather, 1999).

Technical efficiency implies use of the available inputs in combinations that allow the farmer to produce more yields (Marchand, 2012). Inefficient farmers in fragile ecosystems such as those living near natural forests like in Mt. Elgon are known to extend their farming activities into natural forest land because they cannot produce enough which comes at a high environmental and ecosystem service cost (Illukpitiya, 2005; Marchand, 2012). However, the type of technology employed (in our case the land management system) has a large bearing on technical efficiency in addition to other factors such as relative factor abundance, farm size, market policy reforms and others (Swinnen, 2009;
Bojnec et al.,2014). Therefore, switching from one management pathway to a more efficient system given local conditions is a prerequisite for increasing yield similar to a technology shift. The objective of this study was to analyse technical efficiency of four production systems in Arabica coffee-banana farming system of the Mt. Elgon in Uganda and assesses possibilities for switching from one system to another.

\section{METHODOLOGY}

Study area. This study was conducted in two neighbouring districts (Sironko and Kapchorwa) on opposite sides of the Mt. Elgon in Eastern Uganda. This area is part of an extinct volcano, with maximum altitude of 4321 m.a.s.l (Mugagga et al., 2012) and lies within $1^{\circ} 8^{\prime} 43^{\prime \prime} \mathrm{N}-1^{\circ} 23^{\prime} 04^{\prime \prime} \mathrm{N}$ and 34'22'26'E$34 \mathrm{o} 26^{\prime} 29^{\prime \prime} \mathrm{E}$. The area is characterised by large montane forests, surrounded by several protected areas adjacent to highly populated agricultural lands. More than two million people live on the foothills between 1000 and 2200 m.a.s.l; and depend on the surrounding forest for ecosystem services (Sassen et al., 2013; Sassen et al., 2015).The main crops grown are Arabica coffee, banana, maize, beans, rice, wheat, millet, sweet and potato (Wasige, 2009; Kansiime et al., 2013).

Sample and data collection. Three subcounties from Sironko and four from Kapchorwa districts were purposively selected due to being the main coffee and banana producing parts in the area. The fourth subcounty in Kapchorwa was selected due to its proximity to the mountain protected area and the high rates of fertiliser use. Altitude was also a major criterion for site selection because it has been shown to be key in shaping land use decisions and practices in Uganda (Mugagga et al., 2012) and clearly relates to analysis of technical efficiency and the shifting phenomenon between production systems. A list of coffee and banana growing households was obtained from the district and sub-county 
personnel, working together with the Uganda Coffee Development Authority personnel. Using spreadsheets, the list was entered in Excel spread sheet and a random sampling technique was employed using the following formula (Equations 1 and 2) (UNC, 2018):

$$
M E=z \sqrt{p(1-p) / n}
$$

also re-arranged as:

$$
n=z^{2} p(1-p) / M E^{2}
$$

Where:

$\mathrm{n}=$ sample size, $\mathrm{z}=\mathrm{z}$-score $(\mathrm{z}=1.96$ for $95 \%$ confidence interval), $p$ is probability of finding a coffee-banana farmer in the sample sites $(\mathrm{P}=0.8)$ and $\mathrm{ME}=$ margin of error $(\mathrm{ME}=0.035)$.

A sample of 453 farmers was selected and interviewed using a structured pre-tested questionnaire. To ensure a more balanced altitudinal representation of the sample, we took care to sample at three altitudes; namely 1000 , 1500 and 2000 m.a.s.l.

Coffee-banana intercrops have been documented to have yield benefits on both crops, as well as micro-environmental effects on the coffee from the shading and mulch provided by banana (van Asten et al., 2011; Jassogne et al., 2013; Rahn et al., 2018). Bongers et al. (2015) clearly documented the coffee-banana system in Uganda as a dominant one, with over $85 \%$ of the plots intercropped and coffee tree density at 0.7 on the plots. In addition, our field observations indicated that farmers direct the key inputs such as manure and fertiliser towards coffee rather than banana, making banana a secondary beneficiary of the inputs.

Given that these inputs form a key part of the production function, we estimated the coffee rather than the banana production function. Coffee harvests were obtained through farmer harvest recall per plot, for the previous two seasons between 2015 and
August 2016 when data were collected. The coffee harvests were recorded as red cherries or parchment, which was later scaled to parchment for uniformity. Outliers were identified using box-plots and scatter plots. Data were collected in the last quarter of 2016 and prepared and entered in SPSS 20.0 and analysed in Stata 14.0 software.

\section{Data analysis}

Coffee production technical efficiency. We estimated a coffee stochastic frontier production function using the single bound procedure as modified by Schmidt and Lovell, (1979), which is an output-oriented measure of technical efficiency. The approach used by Batesse et al. (1996) and Batesse (1997) was used to address the problems of biased estimates, as a result of zero values for some observations, where some farmers did not apply inputs such as fertiliser or manure. We estimated the empirical production function as follows (Equation 3);

$L_{n} Y_{i j k}=\beta_{0}+\beta_{I} L_{n}\left(\right.$ Land $\left._{i j k}\right)+\beta_{2} L_{n}\left(\right.$ Labour $\left._{i j k}\right)+$ $\beta_{3} L_{n}\left(\right.$ HLabour $\left._{i j k}\right)+\beta 4 T_{1 i j k}\left(\right.$ HLabour $\left._{i j k}\right)+\beta_{5} L n$ Fertiliser $_{2 i j k}+\beta_{6} T_{2 i j k}\left(\right.$ Fert $\left._{i j k}\right)+\beta_{7} L_{n}$ Manure $_{3 i j k}+$ $\beta_{8} T_{3 i j k}\left(\right.$ Manure $\left._{i j k}\right)+\beta_{9}\left(\right.$ Age $\left.e_{i j k}\right)+\beta_{10}($ Off-farm $j o b)+\beta_{l l}\left(\operatorname{Sex}_{i j k}\right)+\beta_{12}\left(T L U_{i j k}\right)+\varepsilon_{i j k}$

Where:

$Y_{i} \quad=$ Total annual output $(\mathrm{kg})$ for coffee;

Land $_{i j k} \quad=$ Land (ha) allocated to coffee annually;

Labour $_{i j k}=$ Family labour (man hours) used in production of coffee annually;

HLabour $_{i j k}=$ Hired labour (man hours) used; and in production of coffee annually.

The inefficiency model is estimated with Age, Total Livestock Units (TLUs), farmer's sex, dummy for having off farm employment; $T_{i}=$ 
Dummy for hired labour, fertiliser, and manure used in coffee; $\mathrm{k}=$ crop (coffee) and $i=i^{\text {th }}$ farmer.

We, therefore, assumed that farmers derived utility from production of coffee indirectly through the benefits that accrued due to efficient allocation of resources, resulting into cash from the output. Hence, farmer A enjoyed total utility $U_{T A}$; farmer $\mathrm{B}$ derived total utility $U_{T B}$; and so on. This study made use of a parametric approach to estimate the technical efficiency of coffee production following estimation of stochastic frontier models. This approach has the ability to separate the effects of noise from the effects inefficiency and confound the effects of misspecification of functional form (of both technology and inefficiency) with inefficiency, but generates good results only for single output and multiple inputs (Khai and Yabe, 2011). Given a production frontier model of the form in Equation 4.

$\ln \left(Y_{i k}\right)=\left(X_{i k j} ; \beta_{k}\right)-\varepsilon_{i}$

Where:

$Y_{i k}$ is the output of the $i^{\text {th }}$ farm, $\mathrm{k}^{\text {th }}$ output with $(\mathrm{k}=$ coffee $), X_{i k j}$ is a vector of inputs used by the $i^{\text {th }}$ farm and $\varepsilon_{i}$ is a "composed" error term made up of the symmetric component $V_{i}$ that accounts for random variation in output due to factors outside the farmer's control such as weather and diseases and $U_{i}$ a non-negative random variable associated with technical inefficiency.

Hence; $\varepsilon_{i}=V_{i}-U_{i}$

The technical efficiency of the $i^{\text {th }}$ farm is determined using the equation;

$T E_{i}=\frac{Y_{i}}{\exp \left(X_{i} \beta\right)}=\frac{\exp \left(X_{i} \beta-\varepsilon_{i}\right)}{\exp \left(X_{i} \beta\right)}=\exp \left(-\varepsilon_{i}\right)$
Equation 6 is an output-oriented measure of technical efficiency, which takes a value between 0 and 1 ; indicating the magnitude of coffee output of the $i^{\text {th }}$ farm relative to the output that could be produced by a fully efficient farm, using the same input vector. We hierarchically structured the four intensification pathways as 1 to 4 in order of increasing technical efficiency. A coffee farmer is assigned to a given pathway based on their levels of technical efficiency. For instance, a farmer $i$ is assigned to pathway D if their technical efficiency is $T E_{D i}$, and so on.

\section{Factors affecting switching along a} technical efficiency gradient. We assumed that the farmer will choose an intensification option which gives a maximum technical efficiency once they allocate their scarce resources, as compared to the others. Normally, an ordered logit model is estimated as a parallel lines model. The parallel lines model estimated by ologit is also a special case of the gologit model. The parallel lines model can be written as in equation 7 :

$$
P\left(Y_{i}>j\right)=g(X \beta)=\frac{\exp \left(\alpha_{f}+X_{t} \beta\right)}{1+\left[\exp \left(\alpha_{f}+X_{i} \beta\right)\right]},
$$

$j=1,2, \ldots, M-1$

To model the factors that influence the level of technical efficiency that finally results and the likelihood of transition, a generalised ordered logit (gologit) is chosen as suitable. The generalised logit model had received little attention (Fu, 1999); however, some researchers such as Fujimoto (2005), Liu and Koirala (2012) and Williams (2016), have used it in various social-economic research. The model which is a prototype of the multinomial logit is stated as (Equation 8-11);

$$
P\left(Y_{i}>j\right)=g\left(X \beta_{j}\right)=\frac{\exp \left(\alpha_{f}+X_{i} \beta_{j}\right)}{1+\left[\exp \left(\alpha_{f}+X_{i} \beta_{j}\right)\right]}, j=
$$

$1,2, \ldots, M-1$

Where: 
$\mathrm{M}$ is the number of categories of the ordinal dependent variable.

From the above, it can be determined that the probabilities that $Y$ will take on each of the values $1 \ldots \mathrm{M}$ is equal to

$$
\begin{aligned}
& P\left(Y_{i}=1\right)=1-g\left(X_{i} \beta_{1}\right)= \\
& P\left(Y_{i}=j\right)=g\left(X_{i} \beta_{\mathrm{j}-1}\right)-g\left(X_{i} \beta_{\mathrm{j}}\right) \quad j=2, \ldots, \\
& M-1 \\
& P\left(Y_{i}=M\right)=g\left(X_{i} \beta_{\mathrm{M}-1}\right)
\end{aligned}
$$

When $\mathrm{M}=2$, the gologit model is equivalent to the logistic regression model.

When $\mathrm{M}>2$, the gologit model becomes equivalent to a series of binary logistic regressions where categories of the dependent variable are combined, category 1 is contrasted with categories 2, 3 and 4 ; for $\mathrm{J}=2$ the contrast is between categories 1 and 2 versus 3 and 4; and for $\mathrm{J}=3$, it is categories 1,2 and 3 versus category 4 .

Model robustness checks. The likelihood ratio test showed that the assumptions of parallel lines model were violated $(\mathrm{P}<0.01)$. We estimated both a constrained and unconstrained generalised ordered logit model. The constraints for parallel lines were imposed on elevation variable with $\mathrm{P}=0.75$, but not for other variables. Corrective measures were taken by estimating an auto fitted generalised ordered logit model as suggested by Fu (1999) and Clogg and Shihadeh (1994), to overcome the limitations by estimating unconstrained partial proportional odds models. The final model had a Wald Chi Square of 0.748 $(\mathrm{P}=0.58)$, LR Chi Square of 301.99 $(\mathrm{P}<0.01)$ and pseudo $\mathrm{R}^{2}$ of 0.39 .

\section{RESULTS}

Table 1 shows descriptive statistics of the variables used to estimate the stochastic frontier and the generalised ordered logit models. Majority of the farms were located at an altitude range of 1500-2000 m.a.s.l, and over $60 \%$ of them grew local coffee variety (Bugisu) that was assumed to be less productive and impacted negatively on efficiency. This correlates well with the inefficiency assumptions of this study given that local varieties' performance has been documented to be low and farmers tend to grow these varieties under inefficient systems. Farmers hired more labour in coffee rather than banana farm tasks, with $49 \%$ applying fertiliser and $76 \%$ manure on small land holdings of about 0.3 ha (Table 1$)$.

Arabica coffee and banana yields. Arabica coffee yields ranged between 0.21 and 17.78 metric tonnes ha $^{-1}$ year $^{-1}$ in Kapchorwa and between 0.20 and 7.72 metric tonnes ha ${ }^{-1}$ year ${ }^{-1}$ in Sironko district (Fig. 1). There was a huge locational and intensification pathwayrelated to the coffee yield gap between the two sampling sites and among clusters. Similarly, higher banana yields were recorded in Kapchorwa, the highest being about 20 metric tonnes ha ${ }^{-1}$ year $^{-1}$; than in Sironko district with highest of about 12 metric tonnes ha $^{-1}$ year $^{-1}$; although pathway $\mathrm{C} 2$, the conventional cluster seems to have higher yields followed by $\mathrm{C} 3$, the mildly agroecological cluster; and $\mathrm{C} 4$, the highly agroecological (Fig. 1).

Coffee-banana production efficiency. The stochastic production frontier model for coffee was estimated by the Maximum Likelihood method. Household labour, hired labour, manure applied, and fertiliser were significantly $(\mathrm{P}<0.01)$ and positively associated with coffee yields. Farmers produced $50 \%$ of the maximum possible coffee yield with the current input levels.

The results of the coffee output elasticity indicated that an increase of $10 \%$ in amount of fertiliser applied would lead to a $1.7 \%$ increase in yield. Hired labour intensification had the same impact on coffee yield as that of household labour of $1 \%$ for every $10 \%$ increase in the man hours used. Land 
TABLE 1. Statistics of the variables used in the two models for a study on Arabica coffee-banana system

Variable Mean (Std. dev)

\section{Stochastic frontier model variables}

$\begin{array}{lrl}\text { Annual coffee output (metric tonnes) } & 269.8\end{array}$

$-268.82$

Land under coffee and banana (ha) $\quad 0.284$

$\begin{array}{lr} & -0.303 \\ \text { Household labour used annually (man hours/year) } & 551.73\end{array}$

$-537.53$

Hired labour used annually (man hours/year) $\quad 405.45$

$-396.33$

$\begin{array}{lr}\text { Amount of manure applied annually }(\mathrm{kg}) & 1,150.32 \\ -1,131.39\end{array}$

Amount of fertiliser applied annually $(\mathrm{kg}) \quad 99.86$

$-90.54$

Dummy for using hired labour $(\%) \quad 57.9$

$\begin{array}{ll}\text { Dummy for using fertiliser }(\%) & 48.7\end{array}$

$\begin{array}{ll}\text { Dummy for using manure (\%) } & 76.1\end{array}$

$\begin{array}{lr}\text { Age of household head (years) } & 47.41\end{array}$

$-14.31$

$\begin{array}{ll}\text { Dummy for the farmer having an off-farm employment } & 42.7\end{array}$

Farmer's sex $($ Male $=1$, Female $=0) \quad 52.4$

$\begin{array}{lr}\text { Tropical Livestock Units (TLU) on farm } & 3.82\end{array}$

Generalised ordered Logit model variables

$\begin{array}{ll}\text { Altitude range (1000-1500 m.a.s.l) }(\%) & 28.48\end{array}$

Altitude range (1500-2000 m.a.s.l) (\%) $\quad 55.85$

Altitude range (>2000 m.a.s.l) (\%) $\quad 15.67$

$\begin{array}{lr}\text { Coffee variety(improved) }(\%) & 31.35\end{array}$

Market price of coffee parchment $\left(\mathrm{U} \mathrm{Sh} \mathrm{kg}^{-1}\right) \quad 923.561$

\begin{tabular}{lr} 
Market price of fresh bananas $\left(\mathrm{U} \mathrm{Sh} \mathrm{kg}^{-1}\right)$ & -683.757 \\
\hline
\end{tabular}

$\begin{array}{rr} & 6763.073\end{array}$

Average price of fertiliser in bananas $\left(\mathrm{U} \mathrm{Sh} \mathrm{kg}^{-1}\right) \quad 2,682.61$

$-540.495$

Dummy for using fertiliser (\%) $\quad 48.7$

Dummy for using manure (\%) $\quad 76.1$ 
TABLE 1. Contd.

\begin{tabular}{lc}
\hline Variable & Mean (Std. dev) \\
\hline Household size & 6.573 \\
Banana yield $\left(\mathrm{t} \mathrm{ha}^{-1}\right)$ & -2.855 \\
& 9.796 \\
Coffee yield ( $\mathrm{t} \mathrm{ha}^{-1}$ & -9.37 \\
& 7.639 \\
Elevation (m.a.s.l) & -6.322 \\
& $1,692.99$ \\
Age of household head (years) & -235.9 \\
& 47.41 \\
Total land owned (ha) & -14.31 \\
& 1.21 \\
Tropical Livestock Units (TLU) on farm & -0.91 \\
Estimated distance from the farm to the national park boundary (Km) & 3.82 \\
& -3.66 \\
\end{tabular}

intensification in coffee had the highest impact on yield with a $12 \%$ increase for every $10 \%$ increase in land allocated (Table 2).

The estimated Sigma Squared v $\left(\delta_{v}^{2}\right)$ indicated a good model fit, while the estimated gamma $(\gamma)$ indicated that over $14 \%$ of the variation in coffee output in the Mt. Elgon was due to differences in farmer technical efficiencies. To test for the nullity of the variance parameter, a Generalised Likelihood Ratio test was conducted to inform the importance of the inefficiency component. The null hypothesis was specified as "coffee farmers are technically efficient in production". The null hypothesis was, therefore, rejected at $10 \%$ level of significance since evidence showed existence of significant inefficiency (Table 2).

In order to explain the observed production inefficiencies and efficiency differences, farm and farmer characteristics were also interrogated. The dummies for use of hired labour, fertiliser and male gender significantly $(\mathrm{P}<0.01)$ explained the observed technical efficiency in coffee. For every $10 \%$ increase in use of hired labour and fertiliser, there would be a 6.7 and $6.0 \%$ increase in coffee yield, respectively. If a farmer was male, the yield would be 0.3 times higher than for a female. We rejected the null hypothesis of a constant returns to scale technology and estimated frontier normal production models as linear combinations of coffee land size to control for heteroskedasticity.

Table 2 indicated that the highly agroecological pathway, C4 had the highest level of technical efficiency significantly $(\mathrm{P}<0.01)$ different from pathway $\mathrm{C} 1$ that is low agroecological (Low-input-Low-Output) in nature which had majority of the sampled farmers with little investment in inputs. The highly agroecological pathway registered the highest level of efficiency; while low agroecological pathway had the highest inefficiency, in that farmers under the latter pathway were able to attain an average of $46 \%$ of the maximum attainable coffee yields (Table $3)$. The conventional farmers were in the second position, being able to attain $53 \%$ of the maximum possible output in the current production environment, using the available technologies.

Table 3 indicates that majority of coffee farms operated at efficiency levels within the 

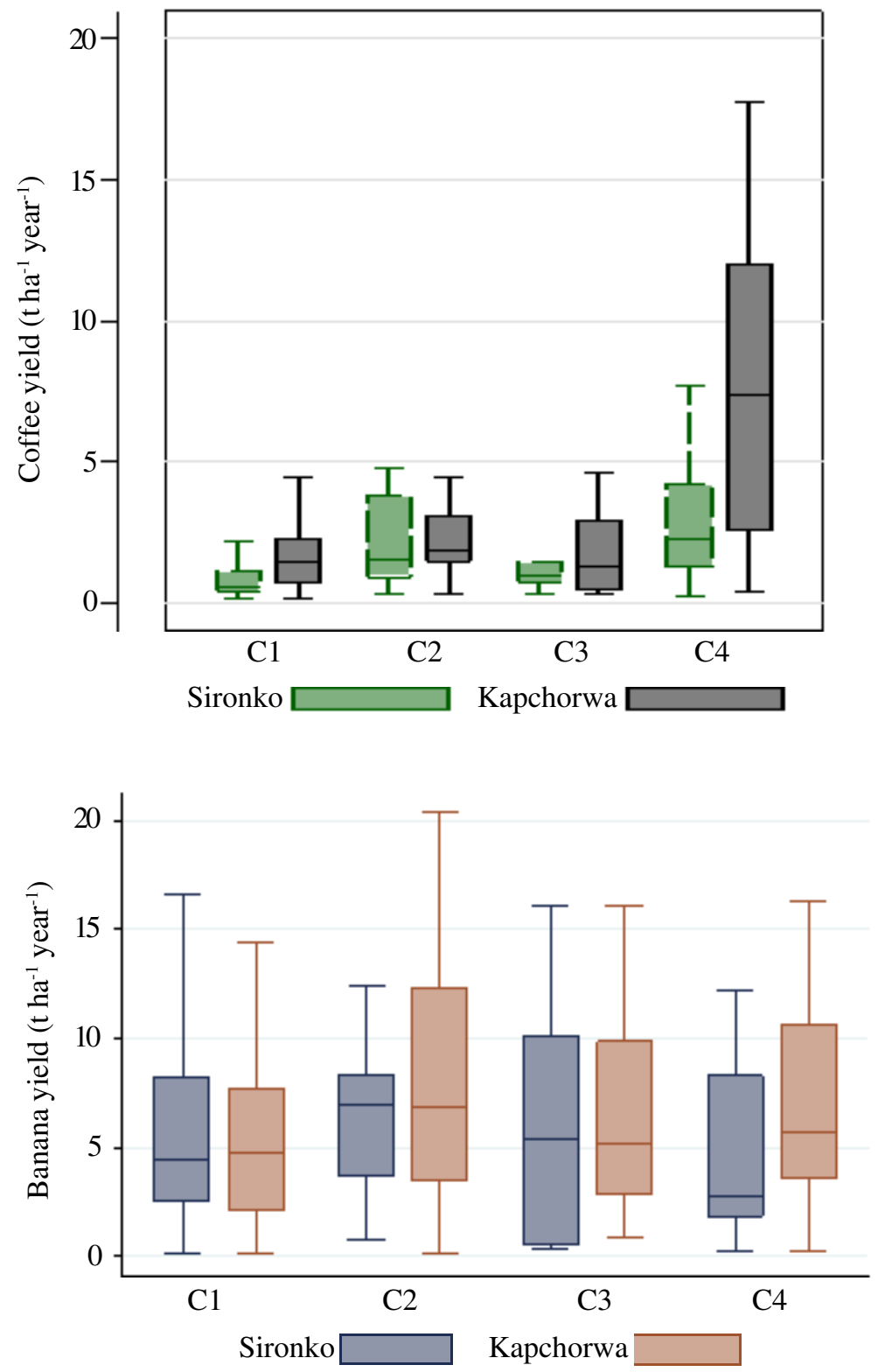

Figure 1. Box plots of actual coffee and banana yields obtained by farmers by intensification cluster ${ }^{1}$ (in the two research districts (Sironko and Kapchorwa) in the Mt. Elgon. The three horizontal lines of the boxes indicate the $75 \%$ percentile (up), median (solid line across boxes) and $25 \%$ percentile (bottom); the upper and bottom bars outside show the maximum and minimum coffee and banana yields respectively. Outliers were removed. C1 = Low-input-low-output, C2 = Conventional, C3 = Mildly agroecological and $\mathrm{C} 4=$ Highly agroecological. 
TABLE 2. The coffee-banana production function stochastic frontier model

\begin{tabular}{lcl}
\hline Dependent variable: Annual coffee output (kg) & Parameter & Coef. (Std. Err.) \\
\hline Constant & $\beta_{0}$ & $4.41(0.21)^{* * *}$ \\
Ln(Land under crop (ha) ) & $\beta_{1}$ & $1.20(0.29)^{* * *}$ \\
LnHousehold labour used annually (man Hours) & $\beta_{2}$ & $0.11(0.03)^{* * *}$ \\
LnHired labour used annually (man Hours) & $\beta_{3}$ & $0.10(0.02)^{* * *}$ \\
Ln(Amount of manure applied annually (kg)) & $\beta_{4}$ & $0.01(0.02)$ \\
LnAmount of fertiliser applied annually (kg) & $\beta_{5}$ & $0.17(0.02)^{* * *}$ \\
& & \\
Inefficiency model & & \\
Dummy for using hired labour & $\delta_{1}$ & $0.67(0.12)^{* * *}$ \\
Dummy for using fertiliser & $\delta_{2}$ & $0.60(0.12)^{* * *}$ \\
Dummy for using manure & $\delta_{3}$ & $0.23(0.14)$ \\
Age of household head (years) & $\delta_{4}$ & $0.003(0.004)$ \\
Dummy for the farmer having an off-farm employment & $\delta_{5}$ & $0.12(0.12)$ \\
Farmer's sex (Male = 1, Female =0) & $\delta_{6}$ & $0.32(0.12)^{* * *}$ \\
Tropical Livestock Units (TLU) on farm & $\delta_{7}$ & $0.02(0.01)$ \\
Constant & $\delta_{8}$ & $4.70(0.27)^{* * *}$
\end{tabular}

\section{Variance parameters}

/nsig2v

/lnsig2u

Gamma

$$
\begin{array}{cc}
\boldsymbol{\delta}_{\boldsymbol{v}}^{\boldsymbol{2}} & -0.39(0.12)^{* * *} \\
\boldsymbol{\delta}_{\boldsymbol{v}}^{\mathbf{2}} & -0.07(0.17) \\
\boldsymbol{\gamma}=\boldsymbol{\delta}_{u}^{\mathbf{2}} /\left(\boldsymbol{\delta}_{v}^{\mathbf{2}}+\boldsymbol{\delta}_{u}^{\mathbf{2}}\right) & 0.14(0.58)
\end{array}
$$

Ln(likelihood)

Test: There is no technical inefficiency component in the model

sigma_u

sigma_v

$\operatorname{Lambda}\left(\delta_{\mathrm{U}} / \delta_{\mathrm{V}}\right)$

Estimated values of efficiency index

Wald chi2(5)

Constant returns to scale hypothesis test

$$
\begin{gathered}
\left(H_{0}: \delta_{U}^{2}=0\right) /\left(H_{1}: \delta_{U}^{2}>0\right): \quad 3.46^{*} \\
\text { prob }>=\text { chibar } 2
\end{gathered}
$$

$\begin{array}{cl}\delta_{\mathrm{U}} & 0.97(0.08)^{* * * *} \\ \delta_{\mathrm{v}} & 0.82(0.05)^{* * *} \\ \lambda & 1.17(0.11)^{* * *} \\ E\left(\exp \left(-u_{i} / \varepsilon_{i}\right)\right. & 0.50(0.19) \\ & 173.7 \\ \text { lincom } & 0.55(0.29)^{*}\end{array}$

Significance levels: $* * * \mathrm{P}<0.01, * * \mathrm{P}<0.05, * \mathrm{P}<0.1$; we estimated a frontier model with heteroscedasticity; we reject the hypothesis that farms use constant returns to scale technology 
TABLE 3. Coffee-banana production technical efficiency estimates by land management system

\begin{tabular}{|c|c|c|c|c|c|}
\hline \multirow[t]{3}{*}{ Efficiency quartile (\%) } & \multirow{3}{*}{$\begin{array}{l}\text { Pooled sample } \\
\qquad(\mathrm{n}=453)\end{array}$} & \multicolumn{4}{|c|}{ Intensification pathway (Percentage) } \\
\hline & & $\begin{array}{l}\text { Low-input-low- } \\
\text { outputn=306) }\end{array}$ & $\begin{array}{l}\text { Conventional } \\
\qquad(\mathrm{n}=65)\end{array}$ & $\begin{array}{c}\text { Mildly } \\
\text { agroecological } \\
(\mathrm{n}=31)\end{array}$ & $\begin{array}{c}\text { Highly } \\
\text { agroecological } \\
(\mathrm{n}=51)\end{array}$ \\
\hline & & $\mathrm{C} 1$ & $\mathrm{C} 2$ & $\mathrm{C} 3$ & $\mathrm{C} 4$ \\
\hline$<0.25$ & 23.18 & 28.76 & 15.38 & 22.58 & 28.76 \\
\hline $0.25-0.50$ & 49.23 & 52.94 & 49.23 & 54.84 & 52.94 \\
\hline $0.50-0.75$ & 26.71 & 18.3 & 35.38 & 22.58 & 18.3 \\
\hline \multirow[t]{2}{*}{$0.75-1.00$} & 0.88 & 0.00 & 0.00 & 0.00 & 0.00 \\
\hline & & ---- & $---\mathrm{Me}$ & --- & ----- \\
\hline Mean TE ${ }^{1}$ & 0.39 & $0.34 * * \mathrm{c} 2$ & $0.42 * * * c 4$ & $0.38 * * * c 4$ & $0.61 * * * \mathrm{c} 1$ \\
\hline Min & 0.01 & 0.01 & 0.01 & 0.12 & 0.30 \\
\hline $\operatorname{Max}$ & 0.81 & 0.74 & 0.70 & 0.69 & 0.81 \\
\hline Std. Dev & 0.19 & 0.17 & 0.17 & 0.15 & 0.14 \\
\hline Proportion of maximum coffee output attained & 0.50 & 0.46 & 0.53 & 0.51 & 0.65 \\
\hline
\end{tabular}


0.25-0.50 quartile across the four intensification pathways. We found that the highly intensified agroecological farms were significantly $(\mathrm{P}<0.01)$ more technically efficient than the conventional or the mildly agroecological farms.

Factors influencing switching among coffee-banana management systems. Table 4 shows results of the Generalised Ordered Logistic models fitting three equations corresponding to the four intensification clusters generated by cluster analysis. The four categories of the outcome variable (Ordered clusters by technical efficiency) were ordered as $\mathrm{C} 4>\mathrm{C} 2>\mathrm{C} 3>\mathrm{C} 1$, following increasing levels of technical efficiency. Altitude, fertiliser use, banana yield and tropical livestock units (TLUs) were significantly and positively associated with transition from lower to higher technically efficient land management clusters. Cluster1, which was the least efficient, had the biggest probability of occurrence $(67 \%)$ among the four; which shows that majority of coffee-banana farmers operated at low efficiency.

Results indicated that only elevation of the farm on the mountain landscape was not significantly associated with level of efficiency (Table 4). Planting an improved variety of coffee had a significant $(\mathrm{P}<0.01)$ and negative effect on farmer transition from Cluster 3 , to the more efficient Clusters 2 and 4 (prop $\mathrm{OR}=0.02)$. However, the same variable was significantly $(\mathrm{P}<0.10)$ and positively associated with a transition from Cluster 2 to 4 (prop $\mathrm{OR}=3.89$ ).

Increased fertiliser use was found to significantly dissuade farmers from practicing conventional intensification (prop $\mathrm{OR}=0.19$, $\mathrm{P}<0.05$ ). The reason for this is that fertilisers were expensive where increased use led to less gains since the coffee prices did not match fertiliser price changes. However, under the mild agroecological intensification (prop $\mathrm{OR}=0.13, \mathrm{P}<0.01$ ), the reason was different. Further interaction with farmers in this cluster revealed that they used fertiliser on other crops other than coffee and banana, hence they valued other high value and short-term crops that generate incomes in a shorter time than coffee. Farmers under the least efficient low agroecological intensification pathway were, however, significantly more likely to transit to a more efficient mild agroecological pathway if they used fertiliser (prop OR=3.55, $\mathrm{P}<0.01$ ) (Table 4). Increasing banana and coffee yields had a similar effect on transition from the low agroecological pathway to the mild agroecological pathway, and from the conventional pathway to the most efficient highly agroecological pathway.

When the size of livestock owned TLUs increased, the likelihood of farmers transiting from Cluster 3 to the more efficient Clusters 2 or 4 significantly increased (prop $\mathrm{OR}=1.38$, $\mathrm{P}<0.01$ ) (Table 4). This is because with more livestock, farmers were able to supplement fertiliser with manure, which increased their efficiency levels and yields, hence encouraging a management transition.

The predicted probability of falling in the agroecological clusters increased significantly $(\mathrm{P}<0.01)$ when the price of fertiliser reduced (Table 5). Halving of price and its reduction to zero were related to macroeconomic interventions that provided fertiliser subsidies to encourage increased consumption or adoption. On the other hand, when the fertiliser price was doubled to say 6,000 Uganda shillings (approximately US\$1.8), the predicted price change was not significant for the most efficient Cluster 4; but significant and positive $(\mathrm{P}<0.05)$ for clusters 1 (Low input-low output) and 3 (Mild-agroecological), yet negative $(\mathrm{P}<0.05)$ for the conventional intensification pathway, C2. This means increasing fertiliser prices discourage the most efficient farmers; while not affecting the less efficient ones because they did not apply it in significant amounts.

\section{DISCUSSION}

As the world increasingly ponders how to feed an increasing population, there is need to find 
TABLE 4. The generalised ordinal Logit model (Unconstrained)

\begin{tabular}{|c|c|c|c|c|c|c|}
\hline \multirow[t]{4}{*}{ Ordered technical efficiency clusters } & \multicolumn{6}{|c|}{ Coffee-banana intensification pathway } \\
\hline & \multirow{2}{*}{\multicolumn{2}{|c|}{$\begin{array}{r}\mathrm{C} 1: \mathrm{Y}>1 \text { vs. } \mathrm{Y}<1 \\
\text { (Low-input-low-output) }\end{array}$}} & \multirow{2}{*}{\multicolumn{2}{|c|}{$\begin{array}{c}\text { C3: Y > } 2 \text { vs. } \mathrm{Y}<2 \\
\text { (Mildly agroecological) }\end{array}$}} & \multirow{2}{*}{\multicolumn{2}{|c|}{$\begin{array}{c}\text { C2: Y > } 3 \text { vs. Y <3 } \\
\text { (Highly conventional) }\end{array}$}} \\
\hline & & & & & & \\
\hline & Coef. (Std. Err.) & OR & Coef. (Std. Err.) & OR & Coef. (Std. Err.) & OR \\
\hline Altitude range (1500-2000 m.a.s.l) (\%) & $0.22(0.48)$ & 1.28 & $2.34(0.68)$ & $9.14 * * *$ & $-0.29(0.74)$ & 0.80 \\
\hline Altitude range (>2000 m.a.s.l) $(\%)$ & $-0.05(0.83)$ & 1.00 & $2.06(1.00) * *$ & 5.92 & $0.10(1.24)$ & 1.44 \\
\hline Coffee variety (improved) $(\%)$ & $0.30(0.43)$ & 1.32 & $-3.64(0.80)$ & $0.02 * * *$ & $1.33(0.80)$ & $3.89 *$ \\
\hline Market price of coffee parchment (USh kg-1) & $-0.00018(0.0002)$ & 1.00 & $-0.00002(0.0004)$ & 1.00 & $0.001(0.0003)$ & $1.00 * * *$ \\
\hline Market price of fresh bananas $\left(\mathrm{USh} \mathrm{kg}^{-1}\right)$ & $0.00002(0.001)$ & 1.00 & $-0.004(0.001)$ & $1.00 * * *$ & $0.001(0.001)$ & 1.00 \\
\hline Average price of fertiliser $\left(\mathrm{USh} \mathrm{kg}^{-1}\right)$ & $0.00009(0.0003)$ & 1.00 & $0.002(0.0005)$ & $1.00 * * *$ & $-0.002(0.001)$ & $1.00 * *$ \\
\hline Dummy for using fertiliser $(\%)$ & $1.24(0.39)$ & $3.55 * * *$ & $-2.06(0.60)$ & $0.13^{* * *}$ & $-1.45(0.77)$ & $0.19 * *$ \\
\hline Dummy for using manure $(\%)$ & $-0.15(0.37)$ & 0.84 & $1.49(0.57)$ & $4.21 * *$ & $-1.13(0.71)$ & 0.36 \\
\hline Household size & $0.01(0.05)$ & 1.01 & $-0.24(0.08)$ & $0.78 * * *$ & $-0.10(0.14)$ & 0.92 \\
\hline Banana yield (tonnes ha') & $0.05(0.01)$ & $1.05 * * *$ & $-0.03(0.01)$ & $0.97 * *$ & $0.03(0.02)$ & 1.03 \\
\hline Coffee yield (tonnes ha-1) & $-0.0003(0.0002)$ & 1.00 & $0.0003(0.0002)$ & 1.00 & $0.001(0.0002)$ & $1.00 * * *$ \\
\hline Elevation (m.a.s.l) & $0.0011(0.001)$ & 1.00 & $0.001(0.001)$ & 1.00 & $0.001(0.001)$ & 1.00 \\
\hline Age of household head (years) & $0.01(0.01)$ & 1.01 & $-0.04(0.02)$ & 0.97 & $-0.07(0.02)$ & $0.93 * * *$ \\
\hline Total land owned (ha) & $0.08(0.05)$ & $1.08 *$ & $0.02(0.05)$ & 1.02 & $0.18(0.08)$ & $1.20 * *$ \\
\hline Total Livestock Units (TLU) on farm & $0.09(0.10)$ & 1.10 & $0.31(0.08)$ & $1.38 * * *$ & $0.04(0.04)$ & 1.04 \\
\hline $\begin{array}{l}\text { Estimated distance from the farm to the } \\
\text { national park boundary }(\mathrm{Km})\end{array}$ & $-0.004(0.01)$ & 1.00 & $0.04(00.02$ & $1.05 * *$ & $0.01(0.01)$ & 1.01 \\
\hline Intercept & $-5.04(2.08)$ & $0.01 * *$ & $-1.96(2.32)$ & 0.04 & $-0.01(2.57)$ & 4.79 \\
\hline Predicted probability $(\mathrm{CI})$ & $0.67(0.62-0.72)$ & & $0.09(0.06-0.12)$ & & $0.15(0.12-0.19)$ & \\
\hline $\mathrm{R}^{2}$ & 0.39 & & & & & \\
\hline Model fit & LR $\chi_{46}^{2}=301.99$ & & & & & \\
\hline
\end{tabular}

Prvalue for reference cluster $\mathrm{C} 4=0.09(0.06-0.12)$; Significance level: *** $\mathrm{P}<0.01, * * \mathrm{P}<0.05 \& * \mathrm{P}<0.10$ 
TABLE 5. Predicted probabilities of key variables

\begin{tabular}{|c|c|c|c|c|c|}
\hline \multirow[t]{2}{*}{ Variable } & \multirow[t]{2}{*}{ Set value } & \multicolumn{4}{|c|}{ Predicted probability (std. err) of being by cluster } \\
\hline & & (Low input-low output) & (Conventional) & (Mildly agroecological) & (Highly agroecological) \\
\hline \multicolumn{6}{|l|}{ Price of fertiliser (US\$/kg) } \\
\hline Zero price & 0.000 & $0.77(0.04)^{* * *}$ & $0.15(0.03)^{* * *}$ & $-0.19(0.07)^{* * *}$ & $0.27(0.08)^{* * *}$ \\
\hline Half price of the current price & 0.45 & $0.74(0.06)^{* * *}$ & $-0.49(0.09)^{* * *}$ & $0.71(0.09)^{* * *}$ & $0.04(0.03)$ \\
\hline Double of current price & 1.80 & $0.67(0.33)^{* *}$ & $-0.67(0.33)^{* *}$ & $1.00(0.0002)^{* * *}$ & $0.0001(0.0002)$ \\
\hline \multicolumn{6}{|l|}{ Elevation } \\
\hline & 1000 & $0.87(0.11)^{* * * *}$ & $0.05(0.12)$ & $-0.04(0.15)$ & $0.13(0.17)$ \\
\hline & 1500 & $0.79(0.05)^{* * *}$ & $0.03(0.06)$ & $0.03(0.07)$ & $0.14(0.06)^{* *}$ \\
\hline & 2000 & $0.69(0.10)^{* * *}$ & $-0.03(0.13)$ & $0.18(0.10)^{*}$ & $0.16(0.10)^{*}$ \\
\hline & 2500 & $0.57(0.28)^{* *}$ & $-0.12(0.37)$ & $0.37(0.30)$ & $0.18(0.27)$ \\
\hline \multicolumn{6}{|l|}{ Farm size (ha) } \\
\hline & 0.5 & $0.78(0.03)^{* * *}$ & $0.001(0.03)$ & $0.10(0.03)^{* * *}$ & $0.12(0.03) * * *$ \\
\hline & 1.0 & $0.77(0.03)^{* * *}$ & $0.006(0.03)$ & $0.09(0.03)^{* * *}$ & $0.13(0.03)^{* * *}$ \\
\hline & 2.5 & $0.75(0.03)^{* * *}$ & $0.02(0.03)$ & $0.06(0.03)^{*}$ & $0.17(0.03)^{* * *}$ \\
\hline & 3.0 & $0.74(0.03)^{* * *}$ & $0.03(0.03)$ & $0.05(0.03)$ & $0.18(0.04)^{* * *}$ \\
\hline & 5.0 & $0.71(0.04) * * *$ & $0.05(0.04)$ & $-0.004(0.052)$ & $0.24(0.06)^{* * *}$ \\
\hline
\end{tabular}

Significance level: $* * * \mathrm{P}<0.01, * * \mathrm{P}<0.05$ and $* \mathrm{P}<0.10$ : Exchange rate: 1 US $\$=3,342$ Uganda Shillings (20th September, 2016) at time of this study survey 
ways of increasing the efficiency of the agricultural production systems in the regions of the world where food is insufficient. Future sustainable food and feed production will involve farmers embracing production systems that give maximum output at the least environmental and economic cost. This study used mixed methods to estimate technical efficiency and after model factors that would affect a technical efficiency gradient transition of farmers within four identified sustainable intensification clusters in the coffee-banana farming system. The clusters were developed from sustainable intensification indicators as spelt out by Delzeit et al. (2018), Haileslassie et al. (2016), Erb et al., 2013 and Firbank et al. (2013).

Arabica coffee and banana yields. Coffee and banana yields responded positively to intensified use of fertiliser and labour. Yields were highest in the conventional pathway $(\mathrm{C} 2)$ where farmers applied relatively higher amounts of fertiliser and in the mildly agroecological pathway where labour use in management was mildly high with a combination of fertiliser. Labour intensification contributed to yield increase because with more labour farmers were able to manage their coffee fields intensively, while complementing the little fertiliser, hence enhancing yields.

Although there is observed reduction in average banana and coffee yields compared to those reported under the same production system by Van Asten et al. (2011) and Bagamba (2007), the maximum yields obtained remain comparable which is an indication that there are inter-farm variations that may attributed to management system differences. Reports of coffee yield gaps as high as $57 \%$ in Eastern Uganda attributed to poor plot level soil and shade management clearly support this argument (Wang et al., 2015).

Coffee-banana production efficiency. Despite the maximum technical efficiencies in coffee being at $81 \%$, the majority of farmers (almost 50\%) operated below 50\% level of efficiency (Table 3 ). This may partly explain the low technical efficiencies compared to the $90 \%$ obtained in coffee by Nchare (2007) in Cameroon highlands. Our findings point to an opportunity of huge technical efficiencyrelated productivity gains for Arabica coffee in Uganda since the most efficient farms lose over $30 \%$ of the maximum attainable yields in cluster $\mathrm{C} 4$ with a TE of $61 \%$ (Table 3 ).

Transition from low to highly intensified agroecological clusters was found to be favoured by increased coffee yields, size of the livestock owned (TLUs) and land owned (Table 4). This means that interventions that lead to increased output and integration of livestock in the production mix can facilitate efficiency and utility-driven transitions. Van Asten et al. (2012) indicated that in the Mt. Elgon, farmers integrate livestock in their coffee and banana production systems to derive utility in terms of food, income and manure. Musa et al. (2012) found that livestock ownership was associated with increased level of resource use efficiency in crop-livestock production in the Ethiopian highlands. In addition, livestock play a safety net and buffer role against risks associated with smallholder farming (Andersson et al., 2011), hence their observed capacity to uplift and aid transition along the efficiency gradient.

Factors influencing switching between management systems. Fertiliser use, especially in the Low-input Low-output system indicated potential to lift coffee-banana farmers from the less efficient and less productive management system to the higher productive systems (Table 4). Given the nature of farmers operating this system, in many cases categorised as subsistence or less commercial, the first production priority is given to food (banana) and this was positively associated with the system, but not coffee yields. In addition, intensified use of low-cost inputs such manure and growing of improved Arabica coffee varieties favoured a transition from the less to more efficient production pathways. Findings by Rahn et al. (2018) and 
Van Asten et al. (2011) have clearly supported the argument for increased input use and adoption of improved varieties to counter the reducing agricultural productivity in the Mt. Elgon. In addition, Bongers et al. (2015) found low adoption potential of improved soil nutrient management and fertilisation, especially the labour-intensive ones such as mulching among coffee-banana farms in Uganda with one third of the farms applying fertiliser which was partly attributed to the limited labour resources.

\section{CONCLUSION}

The objective of this research was to estimate the technical efficiency within the coffeebanana production in four earlier identified management pathways to enable modelling what could drive a farmer switching between and among the coffee-banana management pathways. The research also sought to establish a link between technical efficiency and the type of management pathway a farmer adopts. In this study, efficiency and opportunities for switching from one coffeebanana management system to another are concurrently assessed, although many previous studies have handled the two separately. In terms of policy, the study tested the issue of fertiliser pricing and its implications for sustainable intensification.

Across the four management pathways, majority of the farmers operate in the efficiency bracket of 0.25 and 0.5 , which is indicative of a large room for improvement. Agroecological systems are competitively efficient producers compared to the conventional ones. The common belief that conventional farms are more efficient than the subsistence farms where little or no external inputs are applied is found to be true when we compare the Low-input-low-output coffeebanana production systems, but not true in the case of agroecological ones that apply more external organic inputs such as manure or more labour in management.
Switching from the Low-input-low-output coffee-banana production system to higher efficiency levels is driven by farm size and fertiliser use. On the other hand, switching from the mild agroecological or conventional system to the most technically efficient highly agroecological system is favoured by adoption of improved coffee varieties and integrating livestock in the systems given that this system depends more on labour and manure.

With necessary adjustments in the systems, we find opportunities for switching from one system to another. What remains to be proven is the level of investment needed and willingness of the farmers practicing the various management pathways to switch.

\section{ACKNOWLEDGEMENT}

This research was financed by the Volkswagen Foundation through the African Initiative Project that was managed at Makerere University, Uganda and Justus-Liebig University in Giessen, Germany.

\section{REFERENCES}

Alexandratos, N. and Bruinsma, J. 2012. World agriculture towards 2030/2050: the 2012 revision. (Vol. 12, No. 3). FAO, Rome: ESA Working paper.

Andersson, C., Mekonnen, A. and Stage, J. 2011. Impacts of the Productive Safety Net Program in Ethiopia on livestock and tree holdings of rural households. Journal of Development Economics 94(1):119-126.

Battese, G.E. 1992. Frontier production functions and technical efficiency: a survey of empirical applications in agricultural economics. Agricultural economics 7(34):185-208.

Battese, G.E., Malik, S.J. and Gill, M.A.1996. An investigation of technical inefficiencies of production of wheat farmers in four districts of Pakistan. Journal of Agricultural Economics 47(14):37-49. 
Battese, G.E. 1997. A note on the estimation of Cobb Douglas production functions when some explanatory variables have zero values. Journal of Agricultural Economics 48(13):250-252.

Bojnec, Š., Fertõ, I., Jámbor, A. and Tóth, J. 2014. Determinants of technical efficiency in agriculture in new EU member states from Central and Eastern Europe. Acta Oeconomica 64(2):197-217.

Bongers, G., Fleskens, L., Van de Ven, G., Mukasa, D., Giller, K.E.N. and Van Asten, P. 2015. Diversity in smallholder farms growing coffee and their use of recommended coffee management practices in Uganda. Experimental Agriculture 51(4):594.

Boserup, E. 2014. The conditions of agricultural growth: The economics of agrarian change under population pressure. Routledge. Allan and Urwin, London.

Burton, M.L. and White, D.R. 1984. Sexual division of labor in agriculture. American Anthropologist 86(3):568-583.

Campbell, B.M., Thornton, P., Zougmoré, R., Van Asten, P. and Lipper, L. 2014. Sustainable intensification: What is its role in climate smart agriculture?. Current Opinion in Environmental Sustainability, 8:39-43.

Claessens, L., Knapen, A., Kitutu, M.G., Poesen, J. and Deckers, J.A. 2007. Modelling landslide hazard, soil redistribution and sediment yield of landslides on the Ugandan footslopes of Mount Elgon. Geomorphology 90(1-2):2335.

Clogg, C.C. and Shihadeh, E.S. 1994. Statistical models for ordinal variables (Vol. 4). Sage Publications, Inc.

Delzeit, R., Lewandowski, I., Arslan, A., Cadisch, G., Erisman, J.W., Ewert, F., Klein, A.M., von Haaren, C., LotzeCampen, H., Mauser, W. and Plieninger, T. 2018. How the sustainable intensification of agriculture can contribute to the Sustainable Development Goals. The need for specific socio-ecological solutions at all spatial levels. Working Paper No. 18/ 1.

Drost, D., Long, G., Wilson, D., Miller, B. and Campbell, W. 1996. Barriers to adopting sustainable agricultural practices. Journal of Extension 34(6):1-6.

Ellis, E.C., Klein Goldewijk, K., Siebert, S., Lightman, D. and Ramankutty, N. 2010. Anthropogenic transformation of the biomes, 1700 to 2000. Global Ecology and Biogeography 19(5):589-606.

Erb, K.H., Haberl, H., Jepsen, M.R., Kuemmerle, T., Lindner, M., Müller, D., Verburg, P.H. and Reenberg, A. 2013. A conceptual framework for analysing and measuring land-use intensity. Current Opinion in Environmental Sustainability 5(5):464-470.

Fairweather, J.R.1999. Understanding how farmers choose between organic and conventional production: Results from New Zealand and policy implications. Agriculture and Human Values 16(1):5163.

Firbank, L.G., Elliott, J., Drake, B., Cao, Y. and Gooday, R. 2013. Evidence of sustainable intensification among British farms. Agriculture, Ecosystems \& Environment 173:58-65.

Fu, V.K. 1999. Estimating generalized ordered logit models. Stata Technical Bulletin $8(44)$.

Gracheva, R., Kohler, T., Stadelbauer, J. and Meessen, H. 2012. Population dynamics, changes in land management, and the future of mountain areas in Northern Caucasus: The example of North Ossetia. Erdkunde 197-219.

Grau, R., Kuemmerle, T. and Macchi, L.2013. Beyond 'land sparing versus land sharing': environmental heterogeneity, globalization and the balance between agricultural production and nature conservation. Current Opinion in Environmental Sustainability 5(5):477-483. 
Haileslassie, A., Craufurd, P., Thiagarajah, R., Kumar, S., Whitbread, A., Rathor, A., Blummel, M., Ericsson, P. and Kakumanu, K.R. 2016. Empirical evaluation of sustainability of divergent farms in the dryland farming systems of India. Ecological Indicators 60:710-723.

Hakiza, G.J., Kyetere, D.T., Musoli, P., Wetala, P., Njuki, J., Kucel, P., Aluka, P., Kangire, A. and Ogwang, J. 2009. Coffee wilt disease in Uganda. Coffee Wilt Disease 2849.

Illukpitiya, P. 2005. Technical efficiency in agriculture and dependency on forest resources: An economic analysis of rural households and the conservation of natural forests in Sri Lanka. Economy and Environment Program for Southeast Asia, EEPSEA, Technical Report. Retrieved from: www. idrc. ca/en/ev-99958-201-1Do-TOPIC. html.

Jassogne, L., van Asten, P.J., Wanyama, I. and Baret, P.V. 2013. Perceptions and outlook on intercropping coffee with banana as an opportunity for smallholder coffee farmers in Uganda. International Journal of Agricultural Sustainability 11(2):144-158.

Jiang, B., Bamutaze, Y. and Pilesjö, P.2014. Climate change and land degradation in Africa: a case study in the Mount Elgon region, Uganda. Geo-Spatial Information Science 17(1):39-53.

Kansiime, M.K., Wambugu, S.K. and Shisanya, C.A.2013. Perceived and actual rainfall trends and variability in Eastern Uganda: Implications for community preparedness and response. Journal of Natural Sciences Research 3(8):179-194.

Khai, H.V. and Yabe, M. 2011. Technical efficiency analysis of rice production in Vietnam. Journal of ISSAAS 17(1):135146.

Kitutu, M.G., Muwanga, A., Poesen, J. and Deckers, J.A.2009. Influence of soil properties on landslide occurrences in Bududa district, Eastern Uganda. African
Journal of Agricultural Research 4(7):611620.

Knapen, A., Kitutu, M.G., Poesen, J., Breugelmans, W., Deckers, J. and Muwanga, A. 2006. Landslides in a densely populated county at the footslopes of Mount Elgon (Uganda): Characteristics and causal factors. Geomorphology 73(12):149-165.

Lambin, E.F. and Meyfroidt, P. 2010. Land use transitions: Socio-ecological feedback versus socio-economic change. Land use policy 27(2):108-118.

Lamine, C. 2011. Transition pathways towards a robust ecologization of agriculture and the need for system redesign. Cases from organic farming and IPM. Journal of Rural Studies 27(2):209-219.

Lohr, L. and Salomonsson, L. 2000. Conversion subsidies for organic production: results from Sweden and lessons for the United States. Agricultural Economics 22(2):133-146.

Marchand, S. 2012. The relationship between technical efficiency in agriculture and deforestation in the Brazilian Amazon. Ecological Economics 77:166-175.

Molin, J.P., Motomiya, A.V.D.A., Frasson, F.R., Faulin, G.D.C. and Tosta, W. 2010. Test procedure for variable rate fertilizer on coffee. Acta Scientiarum. Agronomy 32(4):569-575.

Mugagga, F., Kakembo, V. and Buyinza, M. 2012. Land use changes on the slopes of Mount Elgon and the implications for the occurrence of landslides. Catena 90:39-46

Nchare, A. 2007. Analysis of factors affecting technical efficiency of arabica coffee producers in Cameroon. African Economic Research Consortium, Paper No. 163.

Ochola, D., Jogo, W., Ocimati, W., Rietveld, A., Tinzaara, W., Karamura, D.A. and Karamura, E.B. 2013. Farmers' awareness and perceived benefits of agro-ecological intensification practices in banana systems in Uganda. African Journal of Biotechnology 12(29). 
Padel, S. 2001. Conversion to organic farming: a typical example of the diffusion of an innovation? Sociologia Ruralis 41(1):4061.

Rahn, E., Liebig, T., Ghazoul, J., van Asten, P., Läderach, P., Vaast, P., Sarmiento, A., Garcia, C. and Jassogne, L. 2018. Opportunities for sustainable intensification of coffee agro-ecosystems along an altitudinal gradient on Mt. Elgon, Uganda. Agriculture, Ecosystems \& Environment 263:31-40.

Ricketts, T.H., Daily, G.C., Ehrlich, P.R. and Michener, C.D. 2004. Economic value of tropical forest to coffee production. Proceedings of the National Academy of Sciences 101(34):12579-12582.

Ruthenberg, H. 1971. Systems with perennial crops. his Farming Systems in the Tropics (New York: diarendon Press, 1971).

Ruthenberg, H., MacArthur, J.D., Zandstra, H.D. and Collinson, M.P. 1980. Farming systems in the tropics (No. 04; SB111, R8 1980.). Oxford: Clarendon Press.

Ruthenberg, H. 1974. Farming systems in the tropics. Oxford, UK: Clarendon Press.

Sassen, M. and Sheil, D. 2013. Human impacts on forest structure and species richness on the edges of a protected mountain forest in Uganda. Forest Ecology and Management 307:206-218.

Sassen, M., Sheil, D., Giller, K.E. and ter Braak, C.J. 2013. Complex contexts and dynamic drivers: understanding four decades of forest loss and recovery in an East African protected area. Biological Conservation 159:257-268.

Sassen, M., Sheil, D. and Giller, K.E. 2015. Fuelwood collection and its impacts on a protected tropical mountain forest in Uganda. Forest Ecology and Management 354:56-67.

Swinnen, J.F.2009. Reforms, globalization, and endogenous agricultural structures. Agricultural Economics 40:719-732.

Schmidt, P. and Lovell, C.K.1979. Estimating technical and allocative inefficiency relative to stochastic production and cost frontiers. Journal of Econometrics 9(3):343-366.

Tilman, D., Balzer, C., Hill, J. and Befort, B.L. 2011. Global food demand and the sustainable intensification of agriculture. Proceedings of the National Academy of Sciences 108(50):20260-20264.

UNC. 2018. University of North Carolina. Accessed at https://www.unc.edu/ rls/ s151-2010/class23.pdf on 8 September, 2018.

Van Asten, P., Wanyama, I., Mukasa, D., Nansamba, R., Kisaakye, J., Sserubiri, I., Bongers, G. and Jassogne, L. 2012. Mapping and evaluating improved intercrop and soil management options for Ugandan coffee farmers. Technical report. Project executed by the International Institute of Tropical Institute. Funded by Livelihoods and Enterprises for Agricultural Development 90.

Van Asten, P.J., Wairegi, L.W.I., Mukasa, D. and Uringi, N.O. 2011. Agronomic and economic benefits of coffee-banana intercropping in Uganda's smallholder farming systems. Agricultural Systems 104(4):326-334.

Verter, N., Bamwesigye, D. and Darkwah, S.A. 2015. Analysis of Coffee Production and Exports in Uganda. Proceedings ICABR 2015:1083.

Wang, N., Jassogne, L., van Asten, P.J., Mukasa, D., Wanyama, I., Kagezi, G. and Giller, K.E. 2015. Evaluating coffee yield gaps and important biotic, abiotic, and management factors limiting coffee production in Uganda. European Journal of Agronomy 63:1-11.

Wasige, E.J., Tenywa, M.M., Majaliwa, J.G., Bamutaze, Y., Bekunda, M.A. and Lal, R. 2007. Geo-Spatial Analysis for Targeted Natural Resource Management in the Mt. Elgon Areas of Uganda. Soil Science Society of East Africa: Masaka.

Williams, R.2018. GOLOGIT2: Stata module to estimate generalized logistic regression models for ordinal dependent variables. 